\title{
Vitamin E and stress
}

\section{The metabolism of $D-\alpha$-tocopherol in the rat under dietary stress with silver}

\author{
By A. T. DIPLOCK, J. GREEN, J. BUNYAN, D. McHALE \\ AND I. R. MU'THY \\ Walton Oaks Experimental Station, Vitamins Ltd, Tadworth, Surrey
}

$$
\text { (Received } 6 \text { June 1966-Accepted i9 September 1966) }
$$

\begin{abstract}
I. When weanling rats were given a vitamin E-deficient diet and $0.15 \%(\mathrm{w} / \mathrm{v})$ silver acetate in their drinking water, there was a high incidence of liver necrosis and death after 2-4 weeks. This was prevented by $120 \mathrm{ppm} \mathrm{D}-\boldsymbol{\alpha}$-tocopheryl acetate in the diet, was partially prevented by selenium at I ppm but not at $0.05 \mathrm{ppm}$ and was only marginally prevented by $0.15 \%$ DL-methionine.

2. All these effects were observed when the diet was free of fat and when it contained either methyl oleate or polyunsaturated methyl esters. The polyunsaturated lipid slightly increased the velocity of the terminal illness.

3. In spite of the 'anti-vitamin $\mathrm{E}$ ' effect of $\mathrm{Ag}$ and the clear demonstration that $\alpha$-tocopherol played a major part in preventing toxicity, experiments with tracer amounts of $\left[5-\mathrm{Me}-{ }^{11} \mathrm{C}\right]-$ $D-\alpha$-tocopherol showed that rather than there being any destruction of tocopherol in the critical period preceding the onset of disease, there was an increase in tocopherol in the liver due to $\mathrm{Ag}$ administation. The metabolism of tocopherol in the remainder of the animal was unaffected during the pre-necrotic phase.

4. The results are inconsistent with the view that the stress induced by $\mathrm{Ag}$ is caused by a pro-oxidant effect, either in the gastro-intestinal tract or in the tissues of the rat. They show that lipid peroxidation is not a causal factor in the aetiology of Ag-induced liver necrosis and suggest that stress in the vitamin E-deficient animal probably raises the requirement for tocopherol.
\end{abstract}

We have previously described (Green, Diplock, Bunyan, McHale \& Muthy, 1967 ) studies on the effect of dietary unsaturated lipid on the metabolism of $\alpha$-tocopherol in the rat. Little effect was found, even under conditions of massive fat stress, and it was concluded that lipid peroxidation was not a significant biological event in the process leading to vitamin $\mathrm{E}$ deficiency diseases in the rat. In this earlier paper we discussed the biological antioxidant theory of vitamin $E$ action and alternatives to it. If lipid peroxidation is not a causal factor in the onset of deficiency disease it is important to explore further the relationship between unsaturated fatty acid stress and the action of vitamin $\mathrm{E}$. Although this relationship has been studied for many years it needs to be placed in perspective, for unsaturated lipid is not the only stress that can precipitate or aggravate vitamin E deficiency. Harris \& Mason (I956) listed fourteen environmental or dietary agents with stress effects that could be prevented or alleviated by vitamin $\mathrm{E}$, and it would be possible to add several more not included in their summary or that have been discovered since. The relations between these other types of stress and vitamin $E$ are even more obscure than the relationship between unsaturated fat and vitamin E. They do, however, have particular interest, for they enable us to see the relationship between unsaturated fat and vitamin $\mathrm{E}$ not as unique, but as one that should perhaps be viewed against the background of more fundamental processes. 
In the studies presented here we describe silver toxicity in the vitamin E-deficient rat and its effects on the metabolism of small amounts of $\left[{ }^{14} \mathrm{C}\right] \mathrm{D}-\alpha$-tocopherol. Ag salts were first found to be a stress factor in vitamin E-deficient rats by Shaver \& Mason (195I), who described dystrophic lesions, necrotic degeneration of the liver and high mortality in rats given silver nitrate or silver lactate in their drinking water. The subject received little attention afterwards. Mason (1953) mentioned it again, indicating that the rats' diets contained large amounts of cod-liver oil, and described death in coma and full protection by $\alpha$-tocopherol. There seems to be only one other mention in the literature of $\mathrm{Ag}$ as a stress factor, by Dam, Nielsen, Prange \& Søndergaard (1958), who stated that silver acetate at $20 \mathrm{ppm} \mathrm{Ag} \mathrm{had} \mathrm{a} \mathrm{pro-exudative} \mathrm{effect} \mathrm{in}$ vitamin E-deficient chicks. We have studied this particular stress condition in the rat for two reasons: (x) the original account by Shaver \& Mason (195I) described signs superficially similar to those of dietary liver necrosis, which is now known to be due to a combined deficiency of vitamin $\mathrm{E}$ and $\mathrm{Se}$, and (2) there was a suggestion from the work of Mason (1953) that the effect of Ag might depend on the presence of unsaturated fat in the diet and that the stress might be due to an enhancement of lipid peroxidation in vivo.

\section{EXPERIMENTAL AND RESULTS}

\section{Animals and diets}

Rats of the Norwegian hooded strain were used. At 14 days of age they and their dams were given the vitamin E-deficient diet, $\mathrm{AroY}_{3}$ (Bunyan, McHale \& Green, 1963). At 30 days of age the young rats were transferred to the appropriate experimental diet. In Expt I the basal diet had the percentage composition: casein ('low vitamin content'; Genatosan Ltd) 8.3 , lard 6 , cod-liver oil 2, salt mixture 5.33 , glucose 78 , and vitamin mixture 0.4 . The salt mixture supplied $(\mathrm{g} / \mathrm{kg}): \mathrm{NaH}_{2} \mathrm{PO}_{4} \cdot 2 \mathrm{H}_{2} \mathrm{O}$ 26, $\mathrm{CaCO}_{3} \mathrm{I} 8 \cdot 2, \mathrm{KCl} 3.5, \mathrm{Na}_{2} \mathrm{CO}_{3} \mathrm{I} \cdot 2, \mathrm{MgSO}_{4} \cdot 7 \mathrm{H}_{2} \mathrm{O}$ 4, ferric citrate O.I5, $\mathrm{MnSO}_{4} \cdot 4 \mathrm{H}_{2} \mathrm{O} 0 \cdot 2, \mathrm{ZnSO}_{4} \cdot 7 \mathrm{H}_{2} \mathrm{O} 0 \cdot 06, \mathrm{KI} 0.0003, \mathrm{NaF} 0.00025,\left(\mathrm{NH}_{4}\right)_{6} \mathrm{Mo}_{7} \mathrm{O}_{24} \cdot 4 \mathrm{H}_{2} \mathrm{O}$ $0.002, \mathrm{CoSO}_{4} \cdot 7 \mathrm{H}_{2} \mathrm{O} 0.01, \mathrm{Al}_{2} \mathrm{SO}_{4} \cdot \mathrm{K}_{2} \mathrm{SO}_{4} .24 \mathrm{H}_{2} \mathrm{O} 0.0007, \mathrm{CuSO}_{4} \cdot{ }_{5} \mathrm{H}_{2} \mathrm{O}$ 0.02. The vitamin mixture supplied $(\mathrm{mg} / \mathrm{kg})$ : thiamine 9, riboflavine 19 , nicotinic acid 90 , pyridoxine 9, calcium pantothenate 90 , folic acid 2, cyanocobalamin 0.3 , inositol 90 , $p$-aminobenzoic acid 90 , choline dihydrogen tartrate 900 , menaphthone sodium bisulphite $0 \cdot 28$. Vitamin $D_{3}$ was added as a stabilized powder to give $\mathrm{I} \cdot 6$ i.u./g diet. Each rat was also given 300 i.u. vitamin A palmitate per week by mouth, being starved of food for $5 \mathrm{~h}$ before and $\mathrm{i} 7 \mathrm{~h}$ after the dose.

In Expt 2 the basal diet had the percentage composition: casein ('low vitamin content'; Genatosan Ltd) $8 \cdot 3$, salt mixture 5.33 , vitamin mixture $0^{\circ} 4$, and glucose 86 .

\section{Housing, dosage and general experimental methods}

Animals given doses of radioactive tocopherol were housed in individual tube cages, which prevented coprophagy. Details of these and the method of dosage were given by Green $e t a l$. (1967). [5-Me- $\left.{ }^{14} \mathrm{C}\right] \mathrm{D}-\alpha$-tocopherol was prepared from $\mathrm{D}-\gamma$-tocopherol, and methyl oleate and the methyl esters of maize oil and cod-liver oil were prepared as described previously (Green et al. 1967). Methods of tocopherol determination, 
recovery of radioactive tocopherol and its metabolites, and radioactive counting techniques were also as described previously (Green et al. 1967).

\section{Ag and liver necrosis}

Expt I. At 30 days of age rats (of both sexes) were divided into six groups of nine, so that the sex ratio was similar in each group. Groups $\mathrm{I}$ and 2 then received the basal diet. Groups $3^{-6}$ received this diet, supplemented respectively with $0.05 \mathrm{ppm}$ Se (as sodium selenite), I ppm Se (as sodium selenite), I20 ppm $\alpha$-tocopherol, and $100 \mathrm{ppm}$ DPPD $\left(N, N^{\prime}\right.$-diphenyl-p-phenylenediamine). All the rats except those in group I received $0.15 \%(\mathrm{w} / \mathrm{v})$ silver acetate in distilled water to drink from 37 days of age. The rats in group I were given water. Mortality and the incidence of liver degeneration (post mortem) were recorded, and the survivors were killed and examined at 86 days of age. The results are given in Table I. All the rats in group I survived to

Table I. Expt I. Effect of silver acetate in the drinking water of weanling rats given a vitamin-E deficient diet

\begin{tabular}{|c|c|c|c|}
\hline Group & Addition to basal diet & $\begin{array}{l}\text { No. of rats } \\
\text { (male/female) }\end{array}$ & Results* \\
\hline I & None & $9(6 / 3)$ & All normal \\
\hline $2 \dagger$ & None & $9(6 / 3)$ & $\begin{array}{l}\text { All died with liver necrosis } \\
\text { at } 49-64 \text { days (mean } \\
55 \text { days) }\end{array}$ \\
\hline $3 \dagger$ & $\mathrm{Se}, 0.05 \mathrm{ppm}$ & $9(6 / 3)$ & $\begin{array}{l}8 \text { died with liver necrosis } \\
\text { at } 53^{-64} \text { days (mean } \\
58 \text { days) }\end{array}$ \\
\hline $4 \dagger$ & $\mathrm{Se}, \mathrm{I} \cdot \mathrm{Oppm}$ & $9(6 / 3)$ & $\begin{array}{l}4 \text { died with liver necrosis } \\
\text { at } 70-77 \text { days (mean } \\
74 \text { days) }\end{array}$ \\
\hline $5 \dagger$ & $\alpha$-Tocopherol, I20 ppm & I0 $(7 / 3)$ & All normal \\
\hline $6 \uparrow$ & DPPD, I00 ppm & $9(6 / 3)$ & All normal \\
\hline
\end{tabular}

* Survivors killed at 86 days of age.

+ Given $0.15 \%(w / v)$ silver acetate in their drinking water from 37 days of age (i.e. 7 days after start).

86 days and had normal livers. All those in group 2 died by the 64 th day and their livers, post mortem, showed a massive necrosis characterized by a dense mulberry coloration dissimilar in appearance from the nutritional liver necrosis encountered in Se-deficient rats. The casein used contained sufficient Se, even at $8.3 \%$ in the diet, to prevent nutritional liver necrosis (cf. group $\mathrm{r}$ ). Se at the lower level of supplementation was virtually ineffective, but at the higher level about $55 \%$ protection was conferred. The rats that died in group 4 showed characteristic liver lesions. $\alpha$-Tocopherol and DPPD completely protected against Ag toxicity.

Expt 2. This experiment was a study of the effects of dietary lipid, methionine, Se and tocopherol on $\mathrm{Ag}$ poisoning and also of the effect of $\mathrm{Ag}$ on the metabolism of small amounts of $\left[{ }^{14} \mathrm{C}\right] \alpha$-tocopherol. The experiment was large and, for convenience, was divided into three parts. The first part was designed to establish whether Ag toxicity was dependent on the presence of lipid in the diet and, if so, if polyunsaturated fatty 
acids were necessary; whether vitamin $\mathrm{E}$, methionine and Se protected against $\mathrm{Ag}$ toxicity and if any effects they had were dependent on the nature of the dietary lipid, and finally, whether the toxic effect of $\mathrm{Ag}$ could be attributed to an interaction with unsaturated fatty acids in the intestinal tract or in the tissues after absorption. Fifteen groups of four to six rats (of both sexes) were given, at 32 days of age, the diets and treatments shown in Table 2, and the incidence of liver necrosis and mortality was recorded until the rats were 66-73 (mean 72 ) days of age, when the experiment was terminated. The results (Table 2) show that the necrogenic effect of $\mathrm{Ag}$ was completely prevented by vitamin $\mathrm{E}$ (cf. groups $\mathrm{M}, \mathrm{N}$ and $\mathrm{O}$, with, respectively, groups $\mathrm{B}, \mathrm{D}$ and $\mathrm{H}$ ).

Furthermore, the incidence of liver necrosis in rats given $\mathrm{Ag}$ was clearly independent of dietary fat stress, since it was the same in groups $\mathrm{B}, \mathrm{D}$ and $\mathrm{H}$, which received no fat, relatively saturated lipid or highly unsaturated lipid respectively. However, rats receiving the unsaturated lipid (group H) died earlier than those in groups $\mathrm{B}$ and $\mathrm{D}$. Comparison of group $\mathrm{K}$ with group $\mathrm{L}$ shows that there was no difference in either the incidence or velocity of liver necrosis whether the Ag salt was taken at the same time as the unsaturated esters or on alternate days. It would seem from these results, therefore, that the toxic effect is probably not due to enhanced 'peroxidation' of the lipid in the intestinal tract, but to an effect of $\mathrm{Ag}$ in the tissues of the rat. It should be noted that groups $\mathrm{K}$ and $\mathrm{L}$ received only one-half of the total $\mathrm{Ag}$ and unsaturated ester intake of group $\mathrm{H}$; this probably accounts for the increased survival time in groups $\mathrm{K}$ and $\mathrm{L}$ and their apparently lower incidence of liver necrosis. Methionine was without much effect on the toxicity, but, as in Expt I, the high level of Se conferred partial protection (groups $\mathrm{F}$ and $\mathrm{J}$ ), which was independent of dietary lipid. Although liver necrosis was prevented by $\alpha$-tocopherol and (partially) by Se, there was still some mortality in the groups given these treatments $(F, N, J$ and $O$ ). This shows that Ag has some other toxic effect not wholly overcome by vitamin $\mathrm{E}$ or Se in the amounts used.

The second and third parts of the experiment, shown together in Tables 3 and 4 , repeated the conditions of the first part, except that groups $M, N$ and $O$ were omitted. In the second part, thirty-two rats (of both sexes) were divided into eight groups of four, so that each group contained an equal number of males and females. At 35 days of age, each rat was given orally $250 \mu \mathrm{g}(5668 \mathrm{dps})$ of $\left[{ }^{4} \mathrm{C}\right] \mathrm{D}-\alpha$-tocopherol, and $24 \mathrm{~h}$ later the treatments $\mathrm{A}-\mathrm{F}, \mathrm{K}$ and $\mathrm{L}$, described in Table 2, were started. After Io days the rats were killed. Their alimentary tracts were removed, and livers and carcasses from each group were analysed, in pairs, for $\left[{ }^{14} \mathrm{C}\right] \alpha$-tocopherol and its fat-soluble metabolites. In the third part of the experiment thirty-two rats (of both sexes) were divided into four groups, and given the same dose of radioactive tocopherol as above. After $24 \mathrm{~h}$ they were given treatment G, H, I or J, and killed ro days later for analysis as described above.

The analytical results are presented in Tables 3 and 4 . The rather high degree of scatter observed is similar to that found previously when weanlings rather than vitamin E-deficient adult rats were used for radioactive tocopherol experiments (Green $e t$ al. 1967). This was presumably due to uneven depletion of the vitamin $E$ reserve of young 
Vol. 21

3े

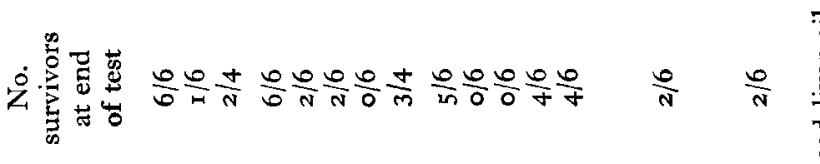

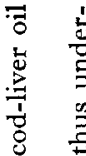

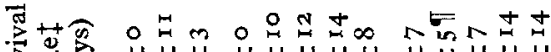

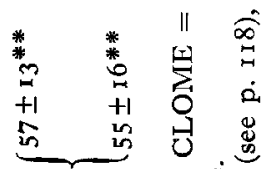

ลे ญे

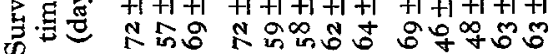

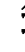

要

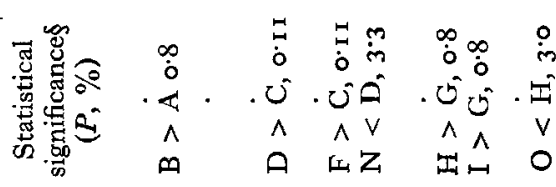

这

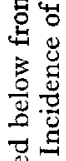

के

उัड

(

7

है

क

:

s.

के

है

窇

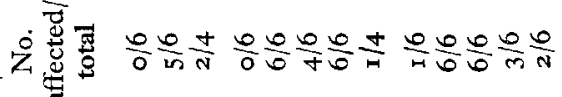

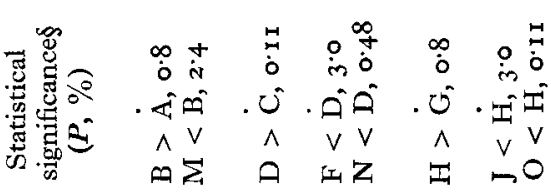

离焉

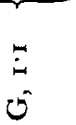

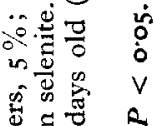

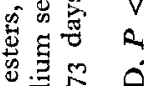

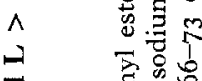

要

氙记

言

点

ษั

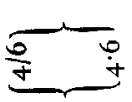

III

된

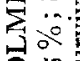

万人

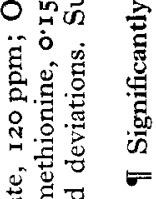

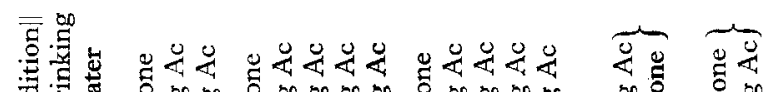

है

宅

莡

نे

i

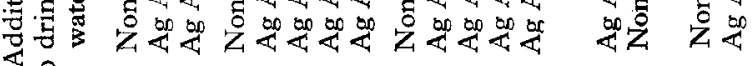

安

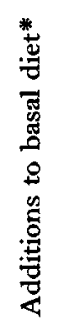

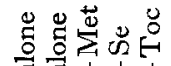

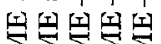

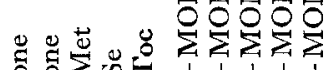

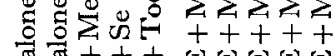

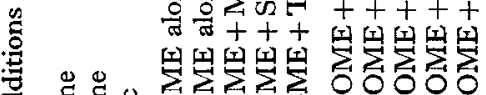

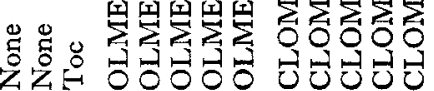

迹
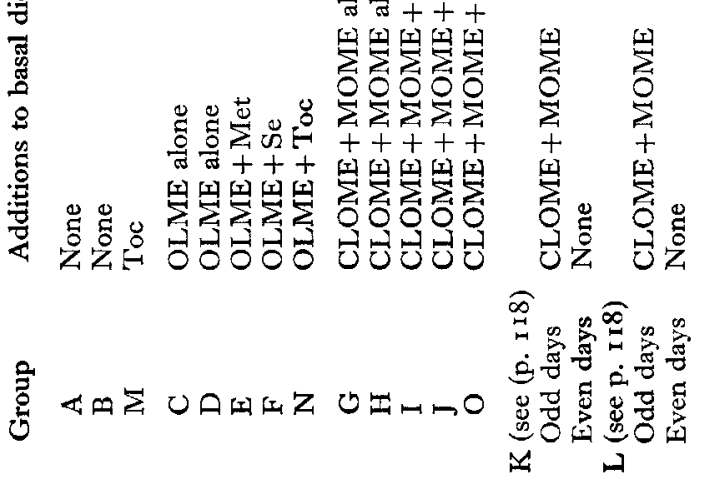

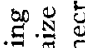

멍

त्रें

离

送

잉

i i $\frac{\pi}{3}$ ह

\&

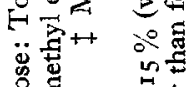

鹿

४ 24000000000

ज्ञ

运 11.

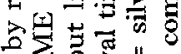

응

要

ㅇํㅇㅝㅝ

in

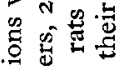

용 of

दे

* 密十总的 
1rats. However, a number of points are revealed by statistical analysis of the results. 'Taking the results as a whole, $\mathrm{Ag}$ treatment significantly raised the concentration of 1tocopherol in liver, but not in the rest of the carcass; neither methionine nor Se affected this. The presence of dietary lipid or its degree of unsaturation was without reffect on tocopherol metabolism; this is consistent with the finding in part I of this

Table 3. Expt 2. Effect of silver, dietary lipid, methionine and selenium on the metabolism of $\left[{ }^{14} \mathrm{C}\right] \alpha$-tocopherol and vitamin $A$ in the livers of weanling rats

(The dietary groups are those given in Table 2 . Each rat was given orally $250 \mu \mathrm{g}$ (5668 dps) $\left[{ }^{14} \mathrm{C}\right] \alpha$-tocopherol $24 \mathrm{~h}$ before treatment began (on the 36 th day of age) and the experiment was terminated after a further ro days. Each result was for a pair of rats)

\begin{tabular}{|c|c|c|c|c|c|c|c|}
\hline \multirow[b]{2}{*}{ Group } & \multirow[b]{2}{*}{$\begin{array}{c}\text { Mean liver } \\
\text { wt (g) }\end{array}$} & \multicolumn{2}{|c|}{$\alpha$-Tocopherol } & \multicolumn{2}{|c|}{$\left[{ }^{14} \mathrm{C}\right]$ metabolites } & \multicolumn{2}{|c|}{ Vitamin A } \\
\hline & & $\begin{array}{l}\text { Replicates } \\
\text { (dps/g) }\end{array}$ & $\begin{array}{c}\text { Mean } \\
(\mathrm{dps} / \mathrm{g})\end{array}$ & $\begin{array}{c}\text { Replicates } \\
\text { (dps/g) }\end{array}$ & $\begin{array}{l}\text { Mean } \\
(\mathrm{dps} / \mathrm{g})\end{array}$ & $\begin{array}{l}\text { Replicates } \\
\text { (i.u./g) }\end{array}$ & $\begin{array}{l}\text { Mean } \\
\text { (i.u./g) }\end{array}$ \\
\hline A & $\begin{array}{l}3 \cdot 15 \\
2 \cdot 18\end{array}$ & $\begin{array}{r}10 \cdot 2 \\
9.0\end{array}$ & $9 \cdot 6 *$ & $\begin{array}{l}17.4 \\
10.6\end{array}$ & $14 \cdot 0^{*}$ & $\begin{array}{l}5 I \\
6 I\end{array}$ & 56 \\
\hline $\mathbf{B}$ & $\begin{array}{l}2 \cdot 53 \\
2 \cdot 33\end{array}$ & $\begin{array}{l}16 \cdot 8 \\
26 \cdot 4\end{array}$ & $21 \cdot 6$ & $15 \cdot 5$ & $15 \cdot 5$ & $\begin{array}{l}92 \\
50\end{array}$ & $7 \mathrm{I}$ \\
\hline $\mathrm{C}$ & $\begin{array}{l}2 \cdot 92 \\
2 \cdot 26\end{array}$ & $\begin{array}{r}14 \cdot 7 \\
8 \cdot 0\end{array}$ & $1 \mathrm{I} \cdot 3 *$ & $\begin{array}{r}10.1 \\
5.9\end{array}$ & $8 \cdot 0^{*}$ & $\begin{array}{l}29 \\
81\end{array}$ & 55 \\
\hline D & $\begin{array}{l}2 \cdot 58 \\
2 \cdot 67\end{array}$ & $\begin{array}{l}19.7 \\
15.8\end{array}$ & $17 \cdot 7$ & $\begin{array}{r}12.4 \\
9 \cdot 1\end{array}$ & 10.8 & $\begin{array}{l}5 I \\
5 I\end{array}$ & $5 I$ \\
\hline $\mathrm{E}$ & 2.49 & I $8 \cdot 5$ & $18 \cdot 5$ & $14 \cdot I$ & $I_{4} \cdot I$ & 87 & 87 \\
\hline $\mathbf{F}$ & $\begin{array}{l}2 \cdot 86 \\
2 \cdot 12\end{array}$ & $\begin{array}{l}21 \cdot 9 \\
12 \cdot 9\end{array}$ & $17 \cdot 4$ & $\begin{array}{r}8 \cdot 6 \\
10 \cdot 5\end{array}$ & $9 \cdot 5$ & $\begin{array}{l}32 \\
63\end{array}$ & 48 \\
\hline $\mathrm{G}$ & $\begin{array}{l}2.65 \\
2.58 \\
3.60\end{array}$ & $\begin{array}{r}13.1 \\
11.5 \\
8.0\end{array}$ & $10.9^{*}$ & $\begin{array}{r}10.8 \\
4.2 \\
2.2\end{array}$ & $5 \cdot 7^{*}$ & $\begin{array}{l}73 \\
59 \\
72\end{array}$ & 68 \\
\hline $\mathrm{H}$ & $\begin{array}{l}2 \cdot 18 \\
3 \cdot 13\end{array}$ & $\begin{array}{l}\text { I } 5.3 \\
13 \cdot 7\end{array}$ & 14.5 & $\begin{array}{l}8 \cdot 5 \\
3 \cdot 3\end{array}$ & $5 \cdot 9$ & $\begin{array}{l}56 \\
82\end{array}$ & 69 \\
\hline $\mathrm{I}$ & $\begin{array}{l}3.05 \\
2.90\end{array}$ & $\begin{array}{l}\text { I7.9 } \\
\text { r } 5.0\end{array}$ & $16 \cdot 5$ & $\begin{array}{l}4 \cdot 2 \\
4 \cdot 8\end{array}$ & $4 \cdot 5$ & $\begin{array}{r}67 \\
121\end{array}$ & 94 \\
\hline $\mathrm{J}$ & $\begin{array}{l}2 \cdot 35 \\
2 \cdot 85 \\
3 \cdot 35\end{array}$ & $\begin{array}{r}12.2 \\
10.0 \\
8.5\end{array}$ & $10 \cdot 2$ & $\begin{array}{l}3 \cdot 7 \\
I \cdot 7 \\
3 \cdot 2\end{array}$ & $2 \cdot 9$ & $\begin{array}{l}51 \\
73 \\
80\end{array}$ & 68 \\
\hline $\mathrm{K}$ & $\begin{array}{l}2 \cdot 17 \\
2 \cdot 24\end{array}$ & $\begin{array}{l}22 \cdot 8 \\
\text { Ir.4 }\end{array}$ & $17 \cdot 1$ & $\begin{array}{l}\text { I } 4 \cdot 7 \\
\text { II.8 }\end{array}$ & $13 \cdot 3$ & $\begin{array}{r}107 \\
83\end{array}$ & 95 \\
\hline $\mathbf{L}$ & $\begin{array}{l}2 \cdot 03 \\
2 \cdot 84\end{array}$ & $\begin{array}{l}29.6 \\
13.5\end{array}$ & $2 \mathrm{I} \cdot 5$ & $\begin{array}{r}15 \cdot 8 \\
9.1\end{array}$ & $12 \cdot 5$ & $\begin{array}{l}85 \\
7 x\end{array}$ & 78 \\
\hline
\end{tabular}

* Results for all those groups not given $\mathrm{Ag}$ were significantly lower than those for groups given $\mathrm{Ag}$ $(P<0.05)$.

experiment that lipid did not affect the incidence of liver necrosis. The increased concentrations of $\left[{ }^{14} \mathrm{C}\right]$ tocopherol in the livers of animals given $\mathrm{Ag}$ were not accompanied by decreases in $\left[{ }^{14} \mathrm{C}\right]$ metabolites; in fact, these metabolites also showed slight increases. Signs of necrosis and fatty infiltration were already visible in the livers of groups $B, D, G, I$ and $J$, showing that the $\left[{ }^{14} \mathrm{C}\right]$ tocopherol metabolism had been studied 
during the biochemically critical pre-necrotic phase. Vitamin A concentrations in liver were apparently unaffected by the nature of the dietary lipid or by the Ag treatment.

Table 4. Expt 2. Effect of silver, dietary lipid, methionine and selenium on the metabolism of $\left[{ }^{14} \mathrm{C}\right] \alpha$-tocopherol in the carcasses of weanling rats

(For details, see Table 2 and p. I 18 . Each analysis was on a pair of rats)

\begin{tabular}{|c|c|c|c|c|c|c|}
\hline \multirow[b]{3}{*}{ Group } & \multirow[b]{3}{*}{$\begin{array}{l}\text { Initial mean } \\
\text { rat wt } \\
\text { (g) }\end{array}$} & \multirow[b]{3}{*}{$\begin{array}{c}\text { Mean gain/ } \\
\text { rat } \\
\text { (g) }\end{array}$} & \multicolumn{4}{|c|}{ Recovery of dose } \\
\hline & & & \multicolumn{2}{|c|}{$\propto$ Tocopherol } & \multicolumn{2}{|c|}{$\left[{ }^{14} \mathrm{C}\right]$ metabolites } \\
\hline & & & $\begin{array}{c}\text { Replicates } \\
(\%)\end{array}$ & $\begin{array}{c}\text { Mean } \\
(\%)\end{array}$ & $\begin{array}{c}\text { Replicates } \\
(\%)\end{array}$ & $\begin{array}{c}\text { Mean } \\
(\%)\end{array}$ \\
\hline \multirow[t]{2}{*}{ A } & $58 \cdot 5$ & -0.5 & $16 \cdot 5$ & & $3 \cdot 3$ & \\
\hline & 43.0 & $1 \cdot 0$ & $9 \cdot 5$ & $13 \cdot 0$ & $4 \cdot I$ & 37 \\
\hline \multirow[t]{2}{*}{$\mathbf{B}$} & $49^{\circ} \circ$ & 0 & $10 \cdot 1$ & & 10.4 & \\
\hline & $47 \cdot 5$ & $\circ$ & 16.7 & 13.4 & $3 \cdot 7$ & $7 \cdot 1$ \\
\hline \multirow[t]{2}{*}{$\mathrm{C}$} & $49 \cdot 5$ & $6 \cdot 5$ & 13.6 & & 8.9 & \\
\hline & $45^{\circ} \circ$ & $1 \cdot 0$ & $5 \cdot 8$ & $9 \cdot 7$ & $1 \cdot 4$ & $5 \cdot 2$ \\
\hline \multirow[t]{2}{*}{$\mathrm{D}$} & $50 \cdot 0$ & -3.5 & $9 \cdot 9$ & & $2 \cdot 8$ & \\
\hline & $58 \cdot 5$ & $-2 \cdot 5$ & $9 \cdot 9$ & $9 \cdot 9$ & $3 \cdot 3$ & $3 \cdot \mathbf{I}$ \\
\hline $\mathbf{E}$ & $5^{8-5}$ & $-I \cdot 5$ & $12 \cdot 3$ & $12 \cdot 3$ & $2 \cdot 5$ & $2 \cdot 5$ \\
\hline \multirow[t]{2}{*}{$F$} & $57 \cdot 0$ & o & $x 9 \cdot 6$ & & $2 \cdot 3$ & \\
\hline & $39 \cdot 5$ & $5 \cdot 0$ & $9 \cdot 7$ & I 4.7 & $3 \cdot 0$ & $2 \cdot 6$ \\
\hline \multirow[t]{3}{*}{ G } & 54.0 & $2 \cdot 0$ & 10.3 & & $3 \cdot 3$ & \\
\hline & $53 \cdot 0$ & $-2 \cdot 0$ & $7 \cdot 9$ & & $2 \cdot 1$ & \\
\hline & $64 \cdot 0$ & $-I \cdot 0$ & $7 \cdot 0$ & $8 \cdot 4$ & $\mathbf{I} \cdot 5$ & $2 \cdot 3$ \\
\hline \multirow[t]{2}{*}{$\mathbf{H}$} & $4^{8 \cdot 0}$ & $-3 \cdot 0$ & $8 \cdot 2$ & & $2 \cdot 4$ & \\
\hline & $55^{\circ} 0$ & $-2 \cdot 0$ & $5 \cdot 7$ & $7 \cdot 0$ & $\mathrm{I} \cdot 9$ & $2 \cdot 2$ \\
\hline \multirow[t]{2}{*}{ I } & 54.0 & $-2 \cdot 0$ & $9 \cdot 5$ & & $2 \cdot 2$ & \\
\hline & $59^{\circ} 0$ & 0 & 9.1 & $9 \cdot 3$ & $1 \cdot 9$ & $2 \cdot I$ \\
\hline \multirow[t]{3}{*}{$\mathbf{J}$} & 46.0 & $-I^{\prime} O$ & $7 \cdot 5$ & & $2 \cdot 0$ & \\
\hline & 59.0 & $-7 \cdot 0$ & $4 \cdot 3$ & & $I \cdot 6$ & \\
\hline & $79^{\circ} \circ$ & $-7 \cdot 0$ & $5 \cdot 5$ & $5 \cdot 8$ & I.O & I. 5 \\
\hline \multirow[t]{2}{*}{$\mathrm{K}$} & 55.5 & -9.0 & 10.1 & & 3.0 & \\
\hline & $68 \cdot 0$ & $-4 \cdot 5$ & $5 \cdot 2$ & $7 \cdot 6$ & $2 \cdot 0$ & $2 \cdot 5$ \\
\hline \multirow[t]{2}{*}{ L } & $5 I \cdot 5$ & -3.5 & 14.2 & & 3.4 & \\
\hline & $45^{\circ} \circ$ & 10.0 & II'5 & $12 \cdot 9$ & $2 \cdot 8$ & $3 \cdot I$ \\
\hline
\end{tabular}

One of the more difficult aspects of the vitamin $\mathrm{E}$ problem is the concept of 'stress' and its effect on vitamin E-deficient animals. There is overwhelming evidence in the literature that 'vitamin $\mathrm{E}$ assists the animal organism in meeting varied types of dietary, chemical and environmental stress, especially during early phases of life. Although the mechanisms involved are often obscure and multiple, when better understood they may assist in revealing the true functions of vitamin $\mathrm{E}$ in metabolic processes' (Harris \& Mason, 1956). Several workers have referred to such stress agents as 'anti-vitamin $\mathrm{E}$ ' substances or 'vitamin $\mathrm{E}$ antagonists', and vitamin $\mathrm{E}$ itself has been called an 'anti-stress' vitamin. Harris \& Mason (1956) tended to regard stress 
as indicative of a state in which peroxidation in vivo is enhanced. They say 'the term [anti-vitamin E] seems inappropriate to cover a situation where the evidence suggests merely a pro-oxidant action of compounds resulting in destruction of tocopherols in vivo'. Ferrando (1956), in a review of stress factors, particularly unsaturated fatty acids and tricresyl phosphate, put forward a similar point of view. Hove (1953a,b) discussed the stress effects of tricresyl phosphate and pyridine poisoning in vitamin $\mathbf{E}$ deficiency and demonstrated that these substances indeed had a pro-oxidant effect in vitro. Miller, Small \& Norris (1955) found that chicks reared on a diet containing ' $\alpha$-protein' (a commercial soya-bean product) developed encephalomalacia, and this they attributed to the stress of sodium bisulphite present in the $\alpha$-protein. They indicated that the effect of the bisulphite may have been mediated by an accelerated development of peroxidation. We have not been able to repeat these results with bisulphite in our laboratories.

Hove (1955), summarizing several years' work on the relation between vitamin $\mathrm{E}$ and stress factors, considered it likely that vitamin $\mathrm{E}$ antagonists such as o-cresyl esters, carbon tetrachloride, pyridine, sulphonamides and sodium sulphite act by promoting the production of lipid peroxides in the tissues, and thus 'increase the need for vitamin E'. It is clear from Hove's (1955) discussion, however, that he regards the phenomena as probably more complicated. Thus, although many of the superficial symptoms of $\mathrm{CCl}_{4}$ poisoning in the rat (liver necrosis, creatinuria and blanching of the incisors) are similar to those found in vitamin E deficiency, the biochemical sequence of events following $\mathrm{CCl}_{4}$ poisoning is apparently complex (Lombardi, 1965) and cannot at present be understood in the relatively simple terms of a pro-oxidative effect (Priest, Smuckler, Iseri \& Benditt, 1962).

There would seem to be two points of view about the relationship between stress and vitamin E. If, as Hove (I955) suggested, the destruction of vitamin E during peroxidation represents the normal pathway and function, stress may be considered to aggravate the signs of vitamin $\mathrm{E}$ deficiency by increasing peroxidation. In other words, stress 'induces a vitamin E deficiency' (Hove, 1949) and 'speeds up the consumption of the vitamin' (Ferrando, 1956). Alternatively, the stress condition can be considered as increasing the metabolic need for vitamin E, perhaps by overwhelming the threshold of an existing mechanism, possibly imposing a new strain that can be counteracted by tocopherol and sometimes by other substances. The results of the experiments described here would seem to exclude the former alternative and favour the latter.

The experiments confirm that $\mathrm{Ag}$ is a toxic agent in the production of liver necrosis in the vitamin E-deficient rat. Its effects can be prevented by vitamin $\mathrm{E}$, and in this sense $\mathrm{Ag}$ may be considered as an 'anti-vitamin $\mathrm{E}$ ' stress factor. Although in the two experiments described here Se, even at r ppm, was only partially protective against $\mathrm{Ag}$ toxicity, in more recent experiments, to be described in a later paper, $\mathrm{Ag}$ was found to produce a high incidence of liver necrosis at considerably lower levels (200 ppm in the drinking water) and, under these conditions, Se was protective at $0.05 \mathrm{ppm}$. It is possible that the necrotic lesions produced by $\mathrm{Ag}$ on the one hand and Se deficiency on the other may be biochemically related. 
Methionine, which is only partially active against the necrosis of Se deficiency, was ineffective against the toxicity of the high levels of $\mathrm{Ag}$ used in Expts I and 2. Its effect against lower levels has not yet been investigated. It was not necessary for unsaturated lipid, or, indeed, any lipid at all, to be present in the diet for the stress effect to manifest itself. Although a slight increase in the velocity of necrosis was found when unsaturated lipid was added to the diet, this may perhaps be attributed to the concomitant and independent stress of polyunsaturated fatty acids. If the antivitamin $\mathrm{E}$ effect of $\mathrm{Ag}$ were due to the initiation or acceleration of lipid peroxidation, it would be reasonable to expect not only a much more dramatic effect following the introduction of unsaturated lipid into the diet, but that this should manifest itself most markedly when the Ag salt and the lipid were allowed to interact in the gastrointestinal tract, for this is where oxidative destruction has been found to be at its maximum (cf. Hickman, Kaley \& Harris, I944). This was not found to be so.

The results of the experiment on the metabolism of $\left[{ }^{14} \mathrm{C}\right]$ tocopherol lead to similar conclusions. Far from there being any evidence that the 'anti-vitamin E' effect of $\mathrm{Ag}$ was associated with tocopherol destruction, as would be found if $\mathrm{Ag}$ were a prooxidant, there was an accumulation or decreased metabolism of $\alpha$-tocopherol in the livers of animals treated with $\mathrm{Ag}$. The metabolic study was made during the critical pre-necrotic phase of the disease in which, if the 'peroxidation' hypothesis is to be accepted, damage to cellular lipids, and therefore by implication to peroxidation inhibitors, must have occurred. The vitamin A content of the liver was not affected by the Ag treatment or by any of the other treatments. This may perhaps be regarded, with some caution, as further evidence that peroxidation processes in the liver are not responsible for the liver damage, for 'present knowledge indicates that vitamin $\mathrm{A}$ is co-oxidized in vivo in a haemoglobin-catalyzed lipid peroxidation' (Tappel, I962). It is concluded that lipid peroxidation cannot be a significant process in the 'antivitamin $\mathrm{E}$ ' effect of $\mathrm{Ag}$. This conclusion supports certain others that we have made about the biological role of vitamin $\mathrm{E}$ (Green et al. 1967; Diplock, Bunyan, McHale \& Green, 1967).

There have been few previous studies of the relation between stress due to agents other than fat and lipid peroxidation. The only quantitative studies are those of Myers $\&$ Mulder (1953a,b), who showed that the production of toxic symptoms by tricresyl phosphate was not related to the destruction of tocopherol in vivo, although the toxicity could be prevented by the administration of vitamin E. Their results, therefore, parallel ours. It should be noted that, although in the experiments of Miller et al. (I955) on the stress effect of sodium bisulphite in chicks the effect was produced only when unsaturated fat was present in the diet, it was shown to be due to the acceleration of oxidative rancidity in the diet before absorption.

How then does vitamin $E$ counteract stress? If attempts are to be made to answer this important question, it would seem to us that some account must be taken of the diversity of the various stress agents themselves and of the complex relationships between them and the many protective agents, which include not only tocopherol, but also Se, antioxidants and sulphur amino acids. Table 5 summarizes some of the more relevant studies on this problem. It is nteresting that Se and methionine, if 
given in excessive amounts, are hepatotoxic agents in the vitamin E-deficient rat and that a combination of methionine and tocopherol, but apparently not cystine, is necessary to overcome the toxic effects of high levels of Se. It may be noted, too, that the protective relationships in, for example, $\mathrm{CCl}_{4}$ poisoning are apparently different from those in methionine poisoning or those in $\mathrm{Ag}$ poisoning; even more remarkable,

Table 5. Summary of some well-defined stress agents for vitamin E-deficient rats and factors found to oppose the stress

\begin{tabular}{|c|c|c|c|c|c|c|c|}
\hline \multirow[b]{2}{*}{ Stress } & \multirow[b]{2}{*}{ Reference } & \multirow[b]{2}{*}{$\underset{\mathrm{E}}{\text { Vitamin }}$} & \multicolumn{4}{|c|}{ Protective agents $t$} & \multirow[b]{2}{*}{ Other factors } \\
\hline & & & $\mathrm{Se}$ & $\begin{array}{l}\text { Methi- } \\
\text { onine }\end{array}$ & Cystine & $\begin{array}{c}\text { Anti- } \\
\text { oxidants }\end{array}$ & \\
\hline Silver & This paper & ++ & + & $?$ & $*$ & ++ & \\
\hline $\mathrm{CCl}_{4}$ & $(1,2,3)$ & ++ & ++ & ++ & ++ & ++ & $\begin{array}{l}\text { Vitamin } \mathrm{B}_{12} \text {; adrenal- } \\
\text { ectomy; phenoxy- } \\
\text { benzamine; anaes- } \\
\text { thetics; antihist- } \\
\text { amines }\end{array}$ \\
\hline $\begin{array}{l}\text { Tricresyl phos- } \\
\text { phate }\end{array}$ & (4) & $+t$ & $*$ & $*$ & $*$ & $*$ & \\
\hline $\begin{array}{l}\text { Synkavite (2- } \\
\text { methylnaphthalene- } \\
\text { 1,3-diol diphos- } \\
\text { phate) }\end{array}$ & (5) & $+t$ & * & * & $*$ & $*$ & \\
\hline Selenate & (6) & + & & $?$ & - & $*$ & $\begin{array}{l}\text { Vitamin } \mathbf{E} \text { highly effec- } \\
\text { tive in combination } \\
\text { with methionine }\end{array}$ \\
\hline $\begin{array}{l}\text { DL-methionine } \\
\text { (at } 2 \% \text { level) }\end{array}$ & (7) & - & - & & $*$ & $*$ & $\begin{array}{l}\text { Glycine, arginine; } \\
\text { vitamin } E \text { and } \\
\text { vitamin } B_{12} \text { in } \\
\text { combination highly } \\
\text { effective }\end{array}$ \\
\hline Hyperoxia & $(8,9)$ & ++ & * & $*$ & $*$ & + & $\begin{array}{l}\text { Glutathione (par- } \\
\text { tially); } \beta \text {-mercapto- } \\
\text { ethylamine; adrenal- } \\
\text { ectomy }\end{array}$ \\
\hline Hypoxia & (IO) & ++ & $*$ & * & $*$ & $*$ & $\begin{array}{l}\text { Thiourea; thyroid- } \\
\text { ectomy }\end{array}$ \\
\hline Allyl alcohol & (II) & + & $*$ & ++ & ++ & $*$ & $\begin{array}{l}\text { Procaine (vitamin } \mathbf{B}_{12} \text {, } \\
\text { choline, glutathione } \\
\text { were inactive) }\end{array}$ \\
\hline
\end{tabular}

+ Degree of protection: ++ , high; + , low; ?, marginal; - , none; $*$ not known.

(I) Hove (I949).

(2) Hove \& Hardin (I95I).

(3) Bangham, Rees \& Shotlander (1962).

(4) Ferrando (1956).

(5) Allison, Moore \& Sharman (1956).

(6) Sellers, You \& Lucas (1950).
(7) Hardin \& Hove (195I).

(8) Hove, Hickman \& Harris (1945).

(9) Telford, Wiswell \& Smith (1954).

(Io) Taylor (I956).

(II) Eger (I956).

perhaps, is the comparison of hyperoxia with hypoxia. Vitamin E-deficient rats are highly susceptible to increased or decreased oxygen tension. Both types of stress can be relieved by an array of 'de-stressing' factors, including thyroidectomy and adrenalectomy. Hyperoxic stress effects are often considered to be caused by the oxidation of 
essential enzymes, perhaps those containing SH groups. Tappel (I962) regards hyperoxia as causing the peroxidation of cellular metabolites, mediated by enhanced free-radical formation. What explanation, therefore, can be given for the effect of hypoxia (Hove et al. 1945; Telford et al. 1954), which is also accentuated by dietary fat and alleviated by vitamin E? Many aspects of the stress problem are inexplicable by present theories of lipid peroxidation and the function of substances such as vitamin $\mathrm{E}$ as biological antioxidants. It would seem that a new unifying concept is necessary.

We wish to thank Miss P. Lewis and Miss I. Thurmer for their technical assistance.

\section{REFERENCES}

Allison, A. C., Moore, T. \& Sharman, I. M. (1956). Br. F. Haemat. 2, 197.

Bangham, A. D., Rees, K. R. \& Shotlander, V. (r962). Nature, Lond. 193, 754.

Bunyan, J., McHale, D. \& Green, J. (I963). Br. F. Nutr. I7, 39 I.

Dam, H., Nielsen, G. K., Prange, I. \& Søndergaard, E. (1958). Nature, Lond. 182, 802.

Diplock, A. T., Bunyan, J., McHale, D. \& Green, J. (1967). Br. F. Nutr, 21, 103.

Eger, (1956). Virchows Arch. Path. Anat. Physiol. 328, 536.

Ferrando, R. (1956). Int. Congr. Vitam. E. III. Venice, 1955, p. 598.

Green, J., Diplock, A. T., Bunyan, J., McHale, D. \& Muthy, I. (I967). Br. F. Nutr. $21,69$.

Hardin, J. O. \& Hove, E. L. (195I). Proc. Soc. exp. Bial. Med. 78, 728.

Harris, P. L. \& Mason, K. E. (1956). Int. congr. Vitam. E. III. Venice, I955, p. I.

Hickman, K. C. D., Kaley, M. W. \& Harris, P. L. (1944). F. biol. Chem. 152, 32 I.

Hove, E. L. (1949). Ann. N.Y. Acad. Sci. 52, 2 I 7.

Hove, E. L. (1953a). F. Nutr. 51, 609.

Hove, E. L. (1953b). F. Nutr. 50, 36 1.

Hove, E. L. (r955). Am. F. clin. Nutr. 3, 328.

Hove, E. L. \& Hardin, J. O. (195I). Proc. exp. Biol. Med. 77, 502.

Hove, E. L., Hickman, K. C. D. \& Harris, P. L. (1945). Archs Biochem. 8, 392.

Lombardi, B. (1965). Fedn Proc. Fedn Am. Socs exp. Biol. 24, 1200.

Mason, K. E. (1953). In Vitamin E in Early Life, p. 179. [R. M. Herriott, editor]. Baltimore: The Johns Hopkins Press.

Miller, R. F., Small, G. \& Norris, L. C. (1955). Y. Nutr. 55, 81.

Myers, D. K. \& Mulder, H. E. W. (1953a). Nature, Lond. 172, 773.

Myers, D. K. \& Mulder, H. E. W. (1953b). Biochem. F. 55, i.

Priest, R. E., Smuckler, E. A., Iseri, O. A. \& Benditt, E. P. (Ig62). Proc. Soc. exp. Biol. Med. 1rI, 50.

Sellers, E. A., You, R. W. \& Lucas, C. C. (1950). Proc. Soc. exp. Biol. Med. 75, 118.

Shaver, S. L. \& Mason, K. E. (195 I). Anat. Rec. ro9, 383.

Tappel, A. L. (1962). Vitams Horm. 20, 493.

Taylor, D. W. (1956). 7. Physiol, Lond. r31, 200.

Telford, I. R., Wiswell, O. B. \& Smith, E. L. (1954). Proc. Soc. exp. Biol. Med. 87, I62. 